\title{
Diversity of ectomycorrhizal symbionts in a disturbed Pinus halepensis plantation in the Mediterranean region
}

\author{
Khalid EL KARKOURI ${ }^{\mathrm{a}, \mathrm{b} *}$, Francis MARTIN ${ }^{\mathrm{c}}$, Daniel MOUSAIN ${ }^{\mathrm{a}}$ \\ ${ }^{a}$ UMR INRA-ENSA.M Sol et Environnement, Équipe Rhizosphère et Symbiose, 2 Place Viala, 34060 Montpellier Cedex 1, France \\ b UMR CNRS 6026 Interactions Cellulaires et Moléculaires, Université de Rennes 1, Campus de Beaulieu, bâtiment 13, 35042 Rennes Cedex, France \\ ${ }^{c}$ UMR INRA-UHP Interactions Arbres/Micro-Organismes, INRA-Nancy, 54280 Champenoux, France
}

(Received 10 September 2003; accepted 3 March 2004)

\begin{abstract}
Ectomycorrhizal diversity (ED) associated with Pinus halepensis trees was examined 1.5 years after outplanting at a fire-disturbed site of Rieucoulon (Hérault, France). ED analysis was examined on non-inoculated and Suillus collinitus-inoculated plants, and on naturally regenerated trees. A total of 461 single ectomycorrhizas was typed using PCR-RFLP analysis and sequencing of the internal transcribed spacer (ITS) of the nuclear rDNA. Twelve ITS RFLP-taxa were detected. The ectomycorrhizal fungus $S$. collinitus (ITS RFLP-taxon 1) was the most abundant (45.8-59.7\%) species in the three treatments, suggesting that it is a strong ectomycorrhizal competitor in this site. S. mediterraneensis (ITS RFLP-taxon 2) was restricted to control and naturally regenerated trees and was unequally moderate (11.7-31.9\%). The remaining belowground ITS RFLP-taxa were uncommon and rare (0.0-9.6\%). The current experimental $P$. halepensis plantation showed a species-poor community dominated by two Suillus species. Ecological strategies of these symbionts are discussed.
\end{abstract}

Pinus halepensis M. / plantation / ectomycorrhizal diversity / PCR-RFLP-sequencing / rDNA (ITS)

Résumé - Diversité ectomycorhizienne dans une plantation à Pinus halepensis. La diversité génétique des ectomycorhizes de plants de $P$. halepensis a été examinée une année et demie après introduction dans un site incendié de Rieucoulon (Hérault, France). Cette diversité a été caractérisée à l'aide du polymorphisme de fragments de restriction (RFLP) et du séquençage de l'espaceur interne transcrit (ITS) de l'ADN ribosomal nucléaire. Trois traitements ont été examinés : des plants témoins, des plants mycorhizés avec Suillus collinitus et des plants en régénération naturelle. Au total, 461 ectomycorhizes ont été soumises au typage moléculaire. Douze ribotypes d'ITS ont été détectés. $S$. collinitus (ribotype 1) est l'espèce dominante $(45,8-59,7 \%$ ) dans les trois traitements suggérant une forte capacité de colonisation dans ce site. La présence de $S$. mediterraneensis (ribotype 2) est limitée aux plants témoins et aux autres issus de la régénération naturelle et sa fréquence est modérée (11,7-31,9\%). Les autres symbiotes ectomycorhiziens sont rares (0,0-9,6\%) et leur abondance diffère d'un traitement à l'autre. Cette étude révèle une faible diversité des symbiotes ectomycorhiziens dans la plantation à $P$. halepensis; elle est dominée par deux espèces du genre Suillus. Les stratégies écologiques de ces symbiotes sont discutées.

Pinus halepensis M. / plantation / diversité des ectomycorhizes / PCR-RFLP-séquençage / ADNr (ITS)

\section{INTRODUCTION}

Aleppo or white pine (Pinus halepensis Miller) is a common, thermophilous and pioneer forest species in the Mediterranean Basin [9]. It can reconstitute a forest in deteriorated soil in a short time, and can contribute to soil conservation against erosion and to the subsequent establishment of oaks in Mediterranean conditions $[1,9,16]$. Considering these ecologically beneficial features, $P$. halepensis has been effectively used for reforestation and desertification control in harsh Mediterranean environments characterized by drought stress and nutrient deficiency $[1,9,24]$. However, its autecology is dependent on its ability to contract mutualistic associations with ectomycorrhizal fungi. Ectomycorrhizal symbionts are known for their ability to enhance adaptability, growth, mineral nutrition and water absorption of forest trees $[22,25]$. Very little is known about
$P$. halepensis ectomycorrhizal diversity (ED) in the early stage of forest development in Mediterranean conditions. Many ectomycorrhizal fungi of $P$. halepensis have been identified and characterized in vitro in containerized or bioassay mycorrhizal tests or from mature forests [11, 27, 28]. However, the most commonly used and encountered ectomycorrhizal symbiont in association with $P$. halepensis species is Suillus collinitus (Fr.) O. Kuntze [11, 15, 27, 28].

$P$. halepensis contains bio-polymers and essential oils which make this forest tree highly susceptible to fire [9, 20]. However, very little information is available on $P$. halepensis ED following disturbances such as fire. The ability of ectomycorrhizal fungi to survive and resist these disturbances depends on the duration and intensity of the disturbance, and the environmental conditions [6, 18, 28]. For instance, the diversity of $P$. halepensis ectomycorrhizal basidiomycetes and the number

\footnotetext{
*Corresponding author: khalid.elkarkouri@univ-rennes1.fr; khalid.2@wanadoo.fr
} 
of Cenococcum sclerotia were lower and higher in burned as compared to unburned stands, respectively [28]. Ectomycorrhizal infection via resistant propagules was also demonstrated in both naturally regenerated and mycorrhizal bioassays of $P$. muricata following fire disturbance $[5,26]$. Surveys of ED following disturbances in young plantations, in naturally regenerated plants and in mature forests are therefore needed to improve our understanding of the ecological strategy and to design pre-selection of mycorrhizal species for inoculation programs in both nurseries and plantations.

The current investigation examined the ectomycorrhizal diversity (ED) of $P$. halepensis 1.5 years after outplanting at a disturbed experimental site. This was carried out on introduced (control and mycorrhizal) plants and those naturally established. ED analysis was performed directly from below-ground ectomycorrhizae (ECM) using PCR-RFLP and sequencing of nuclear rDNA (ITS).

\section{MATERIALS AND METHODS}

\subsection{The Rieucoulon site}

The Rieucoulon site is a mature (20-30 year-old) forest of Pinus halepensis located in Prades-le-Lez (Hérault) in the south of France. Plant community of this forest includes shrubs (Quercus coccifera, Juniperus oxycedrus, Quercus ilex, Thymus vulgaris and Rosmarinus officinalis) and herbaceous plants (Lavandula latifolia, Sanguisorba minor, Argyrolobium zanonii, Bituminaria bituminosa, Aphyllanthes monspeliensis, Barlia robertiana, Rosa sp., Brachypodium sp., Phillyrea angustifolia, Eryngium campestre, Odontites luteus and Carex sp.). In autumn 2000, a survey of a macrofungal $P$. halepensis forest at the Rieucoulon site indicated the presence of Suillus collinitus, $S$. mediterraneensis, Xerocomus subtomentosus, Tricholoma fracticum, Lactarius sanguifluus, L. mairei, Cortinarius elegantior var. quercilicis, Volvariella taylori, Inocybe cervicolor, Russula sp., Clitocybe sp. In 1991, a fire destroyed part of the Rieucoulon forest. The climate is Mediterranean with annual and summer rainfalls of 856 and $122 \mathrm{~mm}$ and mean temperatures of 1.5 and $28.6^{\circ} \mathrm{C}$ in January and July, respectively.

\section{2. $P$. halepensis nursery seedlings}

Seedlings were prepared at the Pépinière Forestière de l'État (DDAF, Les Milles, Aix-en-Provence, Bouches-du-Rhône, France). Seeds of P. halepensis (provenance: 02-Provence, Vilmorin, France) were disinfected and sowed on March 1996 in a sterilized peat-vermiculite mixture $(1: 1, \mathrm{v} / \mathrm{v})$ containing milled rock phosphate $(1 \mathrm{~g}$ per plant) in containers, according to nursery procedures [3]. Seedlings were watered at $4 \mathrm{~L} / \mathrm{m}^{2} / 192$ plants/day. They were then fertilised for 10 weeks with a $0.1 \%$ nutrient solution $\left(\mathrm{N}^{-} \mathrm{P}_{2} \mathrm{O}_{5}-\mathrm{K}_{2} \mathrm{O} 12-0-8 \%\right.$, Dynaflor, Sète, France), two weeks after inoculation. Two distinct $P$. halepensis treatments [control seedlings (C) and seedlings inoculated (M) with S. collinitus (strain J 3-15-32)] were carried out. Seedlings were inoculated in May 1996 as described by Argillier et al. [4]. All inoculated seedlings showed ectomycorrhizal morphotypes similar to $S$. collinitus/P. halepensis ECM 4 months following inoculation [29]. This identity was confirmed using ITS RFLP analysis (data not shown). By contrast, no ectomycorrhiza was observed in non-inoculated seedlings after visual inspection of $P$. halepensis root systems.

\subsection{Experimental plantation}

The experimental plantation is located within the burned area of the Rieucoulon site on a 10\% slope (GPS ProXRS Lambert II coordi- nates, X: $724084 \mathrm{~m}, \mathrm{Y}: 1859144 \mathrm{~m}$; elevation $=85 \mathrm{~m}$ ). Soil is a mineral calcareous marly type soil without a litter layer. In 1995, rare and scattered old $P$. halepensis trees, and naturally-regenerated $P$. halepensis and Quercus spp. seedlings were found. The soil was ploughed to a depth of $80 \mathrm{~cm}$ in October 1995. The C and M P. halepensis seedlings were introduced in three plots (I, II and III) in December 1996. Each plot was heterogeneous and contained both C and M treatments. Seedlings were planted out in lines $4.5 \mathrm{~m}$ apart. Each line corresponded to $\mathrm{C}$ or $\mathrm{M}$ seedlings. Within each line, they were $2.5 \mathrm{~m}$ from each other. No old trees, and no visible naturally-regenerated $P$. halepensis and Quercus spp. seedlings were found at the time of planting.

\subsection{Sampling plants, roots and ECM}

Seedlings ( $51 \mathrm{C}$ and $46 \mathrm{M}$ ) of the largest plot II $(72 \mathrm{~m} \times 45 \mathrm{~m})$ were considered for sampling and DNA typing. Since fruit body surveys, investigated in Autumn 1997 and Spring 1998, did not reveal the presence of ectomycorrhizal sporophores, P. halepensis ED was examined directly from ECM. The introduced C $(6 \%)$ and $M(20 \%)$ plants were examined in Spring (April-June 1998). At the same time, three naturally regenerated seedlings $(\mathrm{R})$, less than 1.5 years of age, were also collected and their ectomycorrhiza analyzed. These were located between lines of $\mathrm{C}$ and $\mathrm{M}$ seedlings and were considered as a third "treatment". The soil and roots were carefully removed at 5-30 cm depth [12]. Roots ( $1-5$ per plant) were randomly chosen and immediately examined or stored at $+4{ }^{\circ} \mathrm{C}$ for $1-4$ days for further analysis. Single ECM (3-29 per root) were randomly chosen and they corresponded to the highest number of young ECM observed on the excised roots. A total of 461 single ECM from C, M and R plants were excised, washed with $\mathrm{H}_{2} \mathrm{O}_{2}(20 \mathrm{~s})$ followed by immediate rinsing (three times) with autoclaved $\mathrm{H}_{2} \mathrm{O}$. They were then stored in Eppendorf tubes at $-70{ }^{\circ} \mathrm{C}$ for DNA extraction and molecular analysis.

\subsection{Molecular analysis}

Total DNA was extracted from mycelia, fruit bodies and single ECM using the DNeasy Plant Mini Kit according to the manufacturer's recommendations (QIAgen S.A.). The nuclear rDNA internal transcribed spacer (ITS, 3'end of 18S + ITS1 + 5.8S + ITS2 + 5'end of $25 \mathrm{~S})$ was amplified by PCR using ITS1 and ITS4 primers $[17,31]$. PCR amplification was carried out using a PTC-100 thermocycler (MJ Research, Inc. Watertown, MA, USA) [13]. Negative controls (no DNA template) were included in all PCR experiments to check for DNA contamination of reaction mixtures. For RFLP analysis, $10 \mu \mathrm{L}$ aliquots of ITS products were mixed with $1.5 \mu \mathrm{L}$ of the React mix, containing 5 units each of HinfI, MspI or TaqI restriction endonucleases (Gibco BRL, Life Technologies), and adjusted to $15 \mu \mathrm{L}$ with deionized water according to the manufacturer's recommendations. The amplified products and restriction fragments (RFLPs) were electrophoresed on $1.5 \%$ and on 3\% regular (Sigma) and Nusieve (FMC) agarose gels, respectively, stained with ethidium bromide and photographed using the Oncor-Appligene Imager 2.02. Digested pUCBM21 DNA (molecular weight marker VIII, Boehringer Mannheim) was used as a size standard. Sizes of PCR and RFLP fragments were determined using the DNAFRAG v. 3.03 program (National Research Council of Canada). The sequencing reactions were performed on ITS of $S$. collinitus mycelium (strain J.3.15.32) and on 14 ECM randomly chosen from each ITS RFLP-taxon. The double stranded ITS products were then purified using the QIAquick PCR purification Kit (QIAgen) in accordance with the manufacturer's instructions. Both strands were sequenced separately using the BigDye Terminator Cycle Sequencing Kit, the AmpliTaq DNA Polymerase FS (Applied Biosystems, Foster, City, CA, USA) and ITS1 and ITS4 primers. Sequencing products were analysed using the automated ABI PRISM 310 DNA Genetic Analyser (Perkin Elmer-Applied Biosystems) at the DNA Sequencing 
Table I. List and origins of ectomycorrhizal references used in this study.

\begin{tabular}{|c|c|c|c|c|}
\hline Fungal taxa & Strains & Authors and years of isolations & Geographical origins & $\begin{array}{l}\text { Associated } \\
\text { forest trees }\end{array}$ \\
\hline \multirow[t]{2}{*}{ Suillus collinitus (Fr.) O. Kuntze } & $\begin{array}{l}\mathrm{Sc} 6^{*} \\
\mathrm{Sc} 7^{*} \\
\mathrm{Sc} 8^{*}\end{array}$ & El Karkouri K. (2000) & Rieucoulon (Hérault) & P. halepensis $\mathrm{M}$. \\
\hline & $\begin{array}{l}\text { J } 3-15-35^{*} \\
\text { J } 3-15-2^{*} \\
\text { J } 3-15-32^{*} \\
\text { J } 3-15-24^{*}\end{array}$ & $\begin{array}{ll}\text { Conventi S. } & (1998) \\
\text { Mousain D. } & (1991) \\
& (1995) \\
\text { Mauré L. } & (1991)\end{array}$ & $\begin{array}{l}\text { Lauret (Hérault) } \\
\text { La Grande-Motte (Hérault) } \\
\text { Nîmes (Gard) } \\
\text { La Grande-Motte (Hérault) }\end{array}$ & $\begin{array}{l}\text { P. pinea } \mathrm{L} \text {. } \\
\text { P. halepensis } \mathrm{M} \text {. } \\
\text { P. pinea } \mathrm{L} \text {. }\end{array}$ \\
\hline S. mediterraneensis (Jacq. \& Blum) R. & $\begin{array}{l}\mathrm{Sm} 1 * * \\
\mathrm{Sm} 2^{* *} \\
\mathrm{Sm} 3 * * \\
\mathrm{Sm} 4 * \\
\mathrm{Sm} 11^{*} \\
\mathrm{Sm} 12^{*}\end{array}$ & El Karkouri K. (2000) & Rieucoulon (Hérault) & P. halepensis $\mathrm{M}$. \\
\hline Xerocomus subtomentosus (L. :Fr.) Quélet & $\begin{array}{l}\text { Xst } 1 * * \\
\text { Xst2** } \\
\text { Xst } 4 * *\end{array}$ & & & \\
\hline S. bovinus (L. :Fr.) O. Kuntze & $\begin{array}{l}\text { ECM51*** } \\
\text { ECM57*** }\end{array}$ & El Karkouri K. (1998) & Nursery (Bouches-du-Rhône) & $\begin{array}{l}\text { P. nigra A. ssp. } \\
\text { nigra }\end{array}$ \\
\hline S. variegatus (Sw. :Fr.) O. Kuntze & $\begin{array}{l}\mathrm{ECM} 31 * * * \\
\mathrm{ECM} 30^{* * * *}\end{array}$ & & & \\
\hline \multirow[t]{2}{*}{ Rhizopogon rubescens (Corda) Th. Fr. } & $\begin{array}{l}\text { B.S. } 1 * * \\
\text { B.S. } 2^{* *}\end{array}$ & & & $\begin{array}{l}\text { P. nigra A. ssp. } \\
\text { salzmannii }\end{array}$ \\
\hline & R $19-1 *$ & Tillard P. (1990) & & P. nigra A. \\
\hline Thelephora terrestris Fr.:Fr. & T $20-1 *$ & & n.d. & n.d. \\
\hline Cenococcum geophilum Fr. & $\begin{array}{l}\text { Cg Nancy* } \\
\text { Cg SIV* }\end{array}$ & $\begin{array}{l}\text { Fienema (1988) } \\
\text { Kiffer (1974) }\end{array}$ & $\begin{array}{l}\text { Nancy (Meurthe-et-Moselle) } \\
\text { Nancy (Meurthe-et-Moselle) }\end{array}$ & $\begin{array}{l}\text { Tilia sp. } \\
\text { Picea sp. }\end{array}$ \\
\hline
\end{tabular}

*,** and ***: mycelium, fruit body and ectomycorrhizae respectively. P.: Pinus; n.d.: not determined.

Facilities of INRA-Nancy (France). The sequencing data were edited using the Sequencher (Genes Codes Corporation, Ann Arbor, MI, USA) for Macintosh computers.

\subsection{Molecular identification and frequency of ECM}

Each distinct "ITS RFLP-type" shared by ECM was named "ITS RFLP-taxon". To identify these taxa, ITS RFLP patterns and sequences were, respectively, compared with our ITS RFLP-types of identified ectomycorrhizal fruit bodies and mycelia (Tab. I) [12, 18, 23] and with GenBank ITS sequences using the Blastn program (National Center for Biotechnology Information) [2]. Sequences of RFLP-taxa are available in the EMBL database. The relative abundance of ITS RFLP-taxa was calculated by dividing the number of ECM of each ITS RFLP-taxon by the total number of the ECM typed in each treatment.

\section{RESULTS}

PCR-RFLP analysis was performed on 461 single ECM collected from $\mathrm{C}, \mathrm{M}$ and $\mathrm{R} P$. halepensis seedlings. A high percentage (97.2\%) of ITS amplifications was successful indicating that the QIAgen spin column provides clean DNA with low or no inhibitors. In total, $359(77.9 \%)$ ECM showed a single amplified ITS product (570-700 bp in size) and interpretable
RFLP patterns (Tab. II). In contrast, 89 (19.3\%) and $13(2.8 \%)$ ECM showed double ITS amplifications with non-interpretable RFLP patterns and no PCR amplification, respectively (Tab. II).

Twelve distinct ITS RFLP-taxa were found using HinfI, $M s p$ I and TaqI restriction enzymes (Tab. II). ITS RFLP-taxon 1 matched the ITS RFLP-pattern of known $S$. collinitus fruitbodies and mycelia (For an example, see Fig. 1, Tab. II) [8]. S. collinitus species was the most common and dominant (51.1, 59.7 and $45.8 \%$ ) symbiont found on P. halepensis in the three treatments (Fig. 1, Tab. II). ITS RFLP-taxon 2 matched the ITS RFLP-pattern of identified $S$. mediterraneensis fruit bodies and mycelia (Tab. II). ITS sequence of S. mediterraneensis (EMBL ac. \# AJ410860) was very similar (94-96\% of sequence similarities) to ITS sequences of other Suillus species. This species abundance ranged between 12 and $32 \%$ of ECM tips and it was restricted to $\mathrm{C}$ and $\mathrm{R} P$. halepensis treatments, respectively.

Five unmatched RFLP-taxa 3, 7, 9, 11 and 12 (EMBL acs. \# AJ410861, AJ410864, AJ410866, AJ410868 and AJ410869) showed $93 \%, 99 \%, 95 \%, 92 \%$ and $97 \%$ ITS sequence identities with Tylospora, Tuber, Tomentella, Tomentella and Tricholoma species (GenBank acs. \# AF052565, AF003918, U83482, U83482, AF241514 and), respectively. The remaining five ITS RFLP-taxa 4, 6, 8 and 10 (EMBL acs. \# AJ410862, AJ410863, AJ410865 and AJ410867) and 5 did not show sequence homologies with ITS of any known ectomycorrhizal 
Table II. Size of amplified ITS and RFLP fragments and relative abundance of the ectomycorrhizal symbionts found in $P$. halepensis plants.

\begin{tabular}{|c|c|c|c|c|c|c|c|}
\hline \multirow[b]{2}{*}{ ITS RFLP-taxa } & \multicolumn{4}{|c|}{ Uncut ITS and RFLPs (size in bp) } & \multicolumn{3}{|c|}{ Relative abundance (\%) } \\
\hline & ITS & $\operatorname{HinfI}$ & MspI & TaqI & $\mathrm{C}^{*}$ & $M^{*}$ & $\mathrm{R}^{*}$ \\
\hline S. collinitus & 700 & $202 / 145 / 118 / 86 / 77 / 35$ & $408 / 167 / 88 / 49$ & $270 / 96 / 85 / 62$ & 51.1 & 59.7 & 45.8 \\
\hline S. mediterraneensis & 700 & $218 / 135 / 115 / 96 / 77 / 35$ & $412 / 239 / 49$ & $174 / 93 / 66$ & 11.7 & 0.0 & 31.9 \\
\hline RFLP-taxon 3 & 600 & $302 / 292$ & 600 & n.d. & 9.6 & 0.0 & 0.0 \\
\hline RFLP-taxon 4 & 611 & $295 / 169$ & $251 / 206 / 126$ & n.d. & 3.2 & 0.0 & 0.0 \\
\hline RFLP-taxon 5 & 620 & $327 / 259 / 33$ & $484 / 136$ & n.d. & 0.0 & 4.4 & 0.0 \\
\hline RFLP-taxon 6 & 571 & $167 / 156 / 133 / 119$ & $188 / 133 / 100 / 40$ & n.d. & 0.0 & 3.7 & 0.0 \\
\hline RFLP-taxon 7 & 651 & $335 / 177 / 75 / 46$ & 639 & $292 / 68$ & 0.0 & 3.7 & 0.0 \\
\hline RFLP-taxon 8 & 651 & $300 / 168$ & $259 / 211 / 124$ & n.d. & 0.0 & 2.7 & 0.0 \\
\hline RFLP-taxon 9 & 651 & $312 / 197 / 147$ & 647 & $339 / 260 / 60$ & 0.0 & 1.7 & 0.0 \\
\hline RFLP-taxon 10 & 651 & $316 / 176 / 147$ & $445 / 181$ & n.d. & 0.0 & 1.4 & 0.0 \\
\hline RFLP-taxon 11 & 672 & $347 / 326$ & 669 & $339 / 260 / 60$ & 0.0 & 1.0 & 0.0 \\
\hline RFLP-taxon 12 & 672 & $351 / 316$ & 669 & n.d. & 0.0 & 0.3 & 0.0 \\
\hline N. i. & & & & & 19.1 & 19.7 & 18.1 \\
\hline N. PCR & & & & & 5.3 & 1.7 & 4.2 \\
\hline Total (number of ECM) & & & & & $100(94)$ & $100(295)$ & $100(72)$ \\
\hline
\end{tabular}

*: Control (C), mycorrhizal (M) and regenerated (R) plants. N. i.: Non-interpretable RFLP patterns; N. PCR: no PCR amplifications; n.d.: not determined.

HinfI

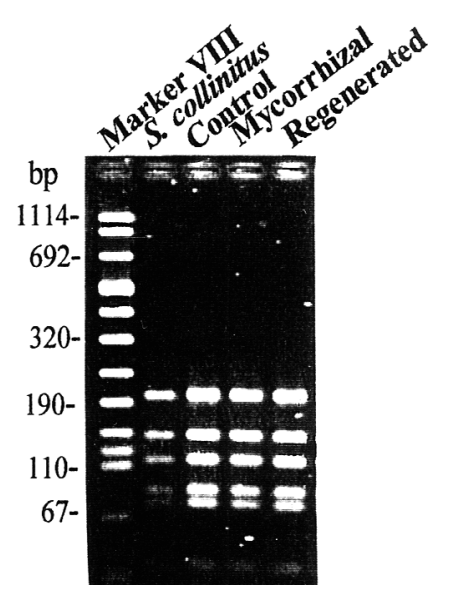

Figure 1. Identification, by HinfI and TaqI RFLP analysis of the ITS, of the dominant species $S$. collinitus in $P$. halepensis seedlings 1.5 years after outplanting at the Rieucoulon site. Marker VIII: molecular weight marker. RFLP patterns corresponded to $S$. collinitus mycelia (see Tab. I) and to ECM from the control, mycorrhizal and naturally regenerated treatments.

species or genus in GenBank database or their ITS region could not be sequenced after two to three replicates. All these ten RFLPtaxa were uncommon or rare $(0.0-9.6 \%)$ on $P$. halepensis.

\section{DISCUSSION}

Ectomycorrhizal diversity in a fire-disturbed $P$. halepensis plantation was investigated 1.5 years after outplanting $S$. collinitus- inoculated seedlings at the Rieucoulon site. Identification of ECM symbionts was performed using PCR-RFLP and sequencing of the nuclear rDNA (ITS) of single ECM. No ectomycorrhizal fruit bodies were found at the time of the surveys. Twelve distinct ITS RFLP-taxa were identified among a total of 461 ECM typed. This finding indicates that there were remaining resident propagules (e.g. spores, hyphae, old and young roots, rhizomorphs) at the outplanting site after fire. They had probably resisted and survived through successive disturbances (fire, soil ploughing) which took place before pine outplanting, as indicated in other studies [5, 26, 28]. Mycorrhizal roots of resprouting plants, such as Quercus spp. and $P$. halepensis, were described to conserve their viability, thus enabling recolonization of introduced $P$. halepensis roots following disturbances $[28,30]$. The current results highlighted that ectomycorrhizal fungi perpetuated via the mycelial network in mature forests [19] could do so in disturbed sites through the remaining resistant propagules. The low $P$. halepensis ED observed here is consistent with previous reports which showed that young Pinus trees are species-poor communities with few dominant species, while mature Pinus forests show stable and high species diversity $[10,12,14,18,21,30]$.

The mycorrhizal fungus $S$. collinitus was the dominant symbiont on inoculated seedlings, but also on non-inoculated and naturally regenerated plants. Although ECM of this species was found 1.5 years after outplanting, no epigeous $S$. collinitus fruit bodies were observed either during Autumn 1997 or Spring 1998 , thus precluding dispersal via spores. S. collinitus therefore seems to propagate via mycelial spread and it appears to be a strong vegetative competitor against other ectomycorrhizal fungi. Abundance of S. collinitus in the three treatments indicated that this symbiont was not influenced by the host treatments, soil type (calcareous marly) or site disturbances. 
S. collinitus seemed to use some characteristics of combative strategists and others of ruderal species at the disturbed Rieucoulon site. This is corroborated by another study which suggested that the ecological strategies of $S$. pungens and overall Suillus spp. combine the two major categories of the R/S/C model [7]. Moreover, the ability of $S$. collinitus species to co-exist in the current young plantation, the Rieucoulon $P$. halepensis forest (see Tab. I) and other mature P. halepensis forests [11, $27,28]$ supports the hypothesis that this species is a multi-stage ectomycorrhizal fungus. This is similar to $S$. brevipes, but not with $S$. tomentosus, which were described to be multi-stage and late-stage fungi in association with $P$. banksiana, respectively [30].

In contrast to $S$. collinitus, $S$. mediterraneensis was associated exclusively with the $\mathrm{C}$ and $\mathrm{R}$ plantlets. This suggests that $S$. mediterraneensis was not influenced by both treatments and showed low competitivity against $S$. collinitus. It was, in addition, outcompeted by $S$. collinitus of the M treatment. Detection of $S$. mediterraneensis together with $S$. collinitus in the $P$. halepensis plantation was consistent with the co-existence of both taxa fruit bodies in the mature $P$. halepensis forest of Rieucoulon. These results, combined with the absence of $S$. mediterraneensis fruit bodies in the $P$. halepensis plantation, suggest that the ecological strategy of this species is similar to that of S. collinitus and it could also be considered as a multistage ectomycorrhizal fungus. The co-existence of both Suillus species might have an ecological significance which could be very interesting to determine. The co-existence of both taxa under young and old $P$. halepensis trees supports their preselection as potential candidates for mycorrhizal applications with $P$. halepensis trees. In addition, co-inoculation tests with both species should be carried out. On the other hand, the other ectomycorrhizal taxa were uncommon and scarce on $P$. halepensis. They may be poor competitors against both Suillus species and/ or their colonisation ability may be influenced by other factors of the Rieucoulon plantation.

Results of the present study indicated that $P$. halepensis trees host a diverse below-ground ectomycorrhizal fungi, especially two Boletales species, S. collinitus and S. mediterraneensis. The survival and adaptation of $P$. halepensis trees on calcareous marly soil may be due to their symbiotic associations with these symbionts. Future investigations on spatio-temporal variations in genetic and functional diversity, with respect to both ECM and potential fruit bodies, will provide a strong ecological background which should enhance management of ectomycorrhizal applications in disturbed Mediterranean stands.

Acknowledgements: This work was funded by the European Contract ERBIC 18 CT-97-0197 (MYRISME) (INCO-DC, DGXII, EU). We thank the Cemagref team (Division Agriculture et Forêt Méditerranéennes, Groupement d'Aix-en-Provence) for the surveys conducted at the Rieucoulon site before outplanting. The authors also thank the Service Régional de la Forêt et du Bois (Direction Régionale de l'Agriculture et de la Forêt du Languedoc-Roussillon) for its logistic support. Dr K. El Karkouri was supported by an INRA post-doctoral grant from MYRISME. The authors are also grateful to Serge Conventi (INRA, Montpellier) for his help in collecting mycorrhizas and to Christine Delaruelle (INRA, Nancy) for DNA sequencing.

\section{REFERENCES}

[1] Agundez D., Degen B., Von Wuehlisch G., Alia R., Multilocus analysis of Pinus halepensis Mill. from Spain: Genetic diversity and clinal variation, Silvae Genet. 48 (1999) 173-178.

[2] Altschul S.F., Madden T.L., Schaffer A.A., Zhang J., Zhang Z., Miller W., Lipman D.J., Gapped BLAST and PSI-BLAST: a new generation of protein database search programs, Nucleic Acids Res. 25 (1997) 3389-3402.

[3] Argillier C., Falconnet G., Gruez J., Production de plants forestiers, in: Guide technique du Forestier méditerranéen français, Chap. 6, Cemagref, France, 1991.

[4] Argillier C., Falconnet G., Tillard P., Mousain D., Essais d'introduction dans un arénosol calcaire de Petite-Camargue de pins pignons (Pinus pinea L.) mycorhizés par Suillus collinitus, Rev. For. Fr. 49 (1997) 131-140.

[5] Baar J., Horton T.R., Kretzer A.M., Bruns T.D., Mycorrhizal colonization of Pinus muricata from resistant propagules after a standreplacing wildfire, New Phytol. 143 (1999) 409-418.

[6] Baxter J.W., Pickett S.T.A., Carreiro M.M., Dighton J., Ectomycorrhizal diversity and community structure in oak forest stands exposed to contrasting anthropogenic impacts, Can. J. Bot. 77 (1999) 771-782.

[7] Bonello P., Bruns T., Gardes M., Genetic structure of natural population of the ectomycorrhizal fungus Suillus pungens, New Phytol. 138 (1998) 533-542.

[8] Bonfante P., Lanfranco L., Genre A., Inter- and intraspecific variability in strains of the ectomycorrhizal fungus Suillus as revealed by molecular techniques, Microbiol. Res. 152 (1997) 287-292.

[9] Brochiero F., Chadioux O., Ripert C., Vennetier M., Autécologie et croissance du pin d'Alep en Provence calcaire, For. Méditerr. 20 (1999) 83-94.

[10] Dahlberg A., Jonsson L., Nylund J.E., Species diversity and distribution of biomass above and below ground among ectomycorrhizal fungi in an old growth Norway spruce forest in South Sweden, Can. J. Bot. 75 (1997) 1323-1335

[11] El Karkouri K., Cleyet-Marel J.C., Mousain D., Isozyme variation and somatic incompatibility in populations of the ectomycorrhizal fungus Suillus collinitus, New Phytol. 134 (1996) 143-153.

[12] El Karkouri K., Martin F., Mousain D., Dominance of the mycorrhizal fungus Rhizopogon rubescens in a plantation of Pinus pinea seedlings inoculated with Suillus collinitus, Ann. For. Sci. 59 (2002) 197-204.

[13] Gardes M., Bruns T., ITS primers with enhanced specificity for basidiomycetes: application to the identification of mycorrhizae and rusts, Mol. Ecol. 2 (1993) 113-118.

[14] Gardes M., Bruns T., Community structure of ectomycorrhizal fungi in a Pinus muricata forest: above- and below-ground views, Can. J. Bot. 74 (1996) 1572-1583.

[15] González-Ochoa A.I., de las Heras J., Torres P., Sánchez-Gómez E. Mycorrhization of Pinus halepensis Mill. and Pinus pinaster Aiton seedlings in two commercial nurseries, Ann. For. Sci. 60 (2003) $43-48$.

[16] Hansens G., Les peuplements mixtes de pin d'Alep et de chênes en Provence, For. Méditerr. 19 (1998) 261-266.

[17] Henrion B., Chevalier G., Martin F., Typing truffle species by PCR amplification of the ribosomal DNA spacers, Mycol. Res. 122 (1994) 289-298.

[18] Jonsson L., Dahlberg A., Nilsson M.C., Zackrisson O., Kårén O., Ectomycorrhizal fungal communities in late-successional Swedish Boreal forests, and their composition following wildfire, Mol. Ecol. 8 (1999) 205-215.

[19] Jonsson L., Dahlberg A., Nilsson M.C., Kårén O., Zackrisson O., Continuity of ectomycorrhizal fungi in self-regenerating boreal Pinus sylvestris forests studied by comparing mycobiont diversity on seedlings and mature trees, New Phytol. 142 (1999) 151-162. 
[20] Kaloustian J., Pauli A.M., Pastor J., Inflammability of Pinus halepensis, Acta Bot. Gallica 145 (1998) 307-313.

[21] Kranabetter J.M., The effect of refuge trees on a paper birch ectomycorrhiza community, Can. J. Bot. 77 (1999) 1523-1528.

[22] Le Tacon F., Mousain D., Garbaye J., Bouchard D., Churin J.L., Argillier C., Amirault J.M., Généré B., Mycorhizes, pépinières et plantations forestières en France, Rev. For. Fr. 49 n ${ }^{\circ}$ sp. (1997) 131-154.

[23] Martin F., Selosse M.A., Di Battista C., Gherbi H., Delaruelle C., Vairelles D., Bouchard D., Le Tacon F., Molecular markers in ecology of ectomycorrhizal fungi, Genet. Sel. Evol. 30 (1998) S333S355.

[24] Roldàn A., Querejeta I., Albaladejo J., Castillo V., Survival and growth of Pinus halepensis Miller seedlings in a semi-arid environment after forest soil transfer, terracing and organic amendments, Ann. Sci. For. 53 (1996) 1099-1112.

[25] Smith S.E., Read D.J., Mycorrhizal symbiosis, Academic Press, London, 1997.

[26] Taylor D.L., Bruns T.D., Community structure of ectomycorrhizal fungi in a Pinus muricata forest: minimal overlap between the mature forest and resistant propagules communities, Mol. Ecol. 8 (1999) 1837-1850.

[27] Torres P., Honrubia M., Inoculation of containerized Pinus halepensis (Miller) seedlings with basidiospores of Pisolithus arhizus (Pers.) Rauschert, Rhizopogon roseolus (Corda) Th. M. Fr. and Suillus collinitus (Fr.) O. Kuntze, Ann. Sci. For. 51 (1994) 521-528.

[28] Torres P., Honrubia M., Changes and effects of a natural fire on ectomycorrhizal inoculum potential of soil in a Pinus halepensis forest, For. Ecol. Manage. 96 (1997) 189-196.

[29] Torres P., Honrubia M., Morte M.A., In vitro synthesis of ectomycorrhizae between Suillus collinitus (Fr.) O. Kuntze and Rhizopogon roseolus (Corda) Th. M. Fr. with Pinus halepensis Miller, Mycotaxon 41 (1991) 437-443.

[30] Visser S., Ectomycorrhizal fungal succession in jack pine stands following wildfire, New Phytol. 129 (1995) 389-401.

[31] White T.J., Bruns T.D., Lee S., Taylor J., Amplification and direct sequencing of fungal ribosomal RNA genes for phylogenetics, in: Innis M.A., Gelfand D.H., Sninsky J.J., White T.J. (Eds.), PCR Protocols, A guide to Methods and Applications, Academic Press, San Diego, 1990, pp. 315-322. 